\title{
Process architecture with strategic indicators in outpatient medical services of high-specialty hospitals
}

\author{
Martha Katty Torres-Salgado* \\ Universidad Nacional Autónoma de México, Faculty of Accounting and Administration, Research Division, Mexico City, Mexico
}

\begin{abstract}
Introduction: The importance of granting high specialty outpatient services calls for a diagnosis through process architecture in order to measure outpatient services deferral with key performance indicators and to evaluate the opportunity of scheduling appointments at high specialty hospitals. Objective: To apply the process architecture model and key performance indicators in high specialty hospitals, in order to analyze outpatient appointment scheduling activities and to improve the quality of medical care and patient safety. Method: Quantitative, sequential and deductive reasoning study, with correlational scope, to assess the degree of association between variables, and to establish and define key performance indicators, according to the importance of activities in medical services. A convenience sample in time and by accessibility to two high specialty hospitals in Mexico City was used. Results: Deferral in outpatient services was measured with an emphasis on the analysis of 19 indicators for a proposal of strategies. Conclusions: The model of priority indicators of the architecture of medical processes is presented through the analysis of activities, which comprehensively visualizes medical care and allows improving the quality of the medical services provided to the patient.
\end{abstract}

KEY WORDS: Process architecture. Model. Key performance indicators. High-specialty hospitals.

\section{Arquitectura de procesos con indicadores estratégicos en los servicios médicos de consulta externa en hospitales de alta especialidad}

\section{Resumen}

Introducción: La importancia de otorgar consulta externa de alta especialidad invita a realizar un diagnóstico a través de la arquitectura de procesos para medir con indicadores el diferimiento de consulta y evaluar la oportunidad de programación de citas en hospitales de alta especialidad. Objetivo: Aplicar el modelo de arquitectura de proceso e indicadores en hospitales de alta especialidad, para analizar las actividades de la programación de citas en consulta externa y mejorar la calidad de la atención médica y seguridad al paciente. Método: Estudio cuantitativo, secuencial y con razonamiento deductivo, de alcance correlacional para evaluar el grado de asociación entre variables, establecer y definir los medidores de desempeño, de acuerdo con la importancia de las actividades en los servicios médicos. Se trabajó una muestra de conveniencia en tiempo y por accesibilidad a dos hospitales de alta especialidad de la Ciudad de México. Resultados: Se midió el diferimiento en consulta externa con relevancia en el análisis de 19 indicadores para una propuesta de estrategias. Conclusiones: El modelo de indicadores prioritarios de arquitectura de procesos médicos a través del análisis de las actividades visualiza integralmente la atención médica y permite mejorar la calidad en el servicio médico al paciente.

PALABRAS CLAVE: Arquitectura de procesos. Modelo. Indicadores. Hospitales de Alta Especialidad.

Correspondence:

*Martha Katty Torres-Salgado

E-mail: katty_torres_salgado@hotmail.com
Gac Med Mex. 2019;155:532-540

Contents available at PubMed

www.gacetamedicademexico.com

0016-3813/@ 2019 Academia Nacional de Medicina de México, A.C.. Published by Permanyer. This is an open access article under the CC BY-NC-ND license (http://creativecommons.org/licenses/by-nc-nd/4.0/). 


\section{Introduction}

In Spain, excessive delays in outpatient services (OS) entail a loss of quality in medical care; deficiencies in the management of OS activity generate dissatisfaction in patients and health professionals. In addition, information systems limitations, which reduce their validity and reliability by presenting data with no appointment dates, which in turn hinders the normalization and permanent updating of the information.

In Peru, in recent years, there has been an increase observed in procrastination for the granting of appointments at Es Salud establishments. This problem is produced by several structural causes related to an increase in the number of insured persons and in the demand for care. ${ }^{2}$ In India, balanced sets of indicators were applied with an integrated approach of structural modeling techniques in order to identify the performance indicators and their relationships with a health system. ${ }^{3}$

In Mexico, the Ministry of Health is aware that the origin of the failure is not corrected from the root at public and private sectors. The workers of the organization know that, even with their maximum effort, they will not be able to meet the expectations of patients or their relatives. ${ }^{4}$

The need to reduce the time to grant medical appointments can be perceived and, although strategies have been implemented through measurement attempts, it has been done in an isolated and not comprehensive way. There is a lack of a detailed analysis in the processes of activities that allows to guarantee the results and, therefore, to prioritize the key performance indicators (KPI) in the comprehensive process architecture of medical services in high specialty hospitals $(\mathrm{HSH})$.

\section{Method}

The purpose of this study is to apply a model of process architecture (PA) priority indicators through the analysis of activities in the scheduling of appointments at OS in order to improve medical care in $\mathrm{HSHs}$, which correspond to tertiary care hospitals with reference services for cardiac and thoracic surgery, neurosurgery and organ transplants, and that have verticality in medical specialties. ${ }^{5}$

This is a research of correlational scope to evaluate the degree of association between variables, establish and define KPIs that can relate their level of priority and behavior in the modeled construct depending on the level of importance of critical, concrete or priority activities, which are clearly distinguished and identified in the value chain as single and distinctive activities that satisfactorily deliver the good or service of the process, or finding out if these activities become a bottleneck that impacts on the delivery of an unsatisfactory good or service, which drives to a problem for this area and to interpersonal conflicts ${ }^{6}$ at different specialty OS.

The hypothesis is that the indicators in priority activities of the OS process have a correlation with the quality and safety offered to the patient in high-specialty hospital services.

\section{Design of the measuring instrument}

In the PA, the in situ visit option was chosen, which consisted of going to the work areas and interviewing the stakeholders involved in the process of care, from its beginning to its conclusion. Interdisciplinary maps drawn on paper or generated with the Visio program were used to establish the sequence of activities that would guide the understanding of the appointment scheduling process. For this, the movement or flow that is carried out at one time was described, and variables that influence on quality and patient safety at the outpatient department were defined, as described in Table 1.

\section{Design of the model of KPIs and process architecture in HSHs}

Models are working hypotheses, an attempt to schematically interpret and describe reality. ${ }^{7}$ In Figure 1, the patient is developed with a single value through $\mathrm{PA}$, and the use of categorical maps and indicators allows to gradually integrate the various medical or supporting areas of the organizational structure:

1. Providers of supplies (stakeholders and owners of the process). To a large extent, there is still dependence on universities and schools or middle and upper level institutes. The resources deriving from teaching processes are those that join hospitals, clinics, sanitaria and offices: general practitioners, specialists and medical support staff.

2. Detection of quality needs. A situational diagnosis is established, which expands the content and delves into the issue of the Mexican health 
Table 1. Conceptual and operational definition of variables

\begin{tabular}{|c|c|c|c|c|c|}
\hline Objective & Quantitative variables & $\begin{array}{l}\text { Conceptual and } \\
\text { theoretical definition }\end{array}$ & $\begin{array}{l}\text { Effectiveness } \\
\text { of variables }\end{array}$ & Instrument & $\begin{array}{l}\text { Source of } \\
\text { information }\end{array}$ \\
\hline $\begin{array}{l}\text { To apply process } \\
\text { architecture and medical } \\
\text { indicators model, } \\
\text { through an analysis of } \\
\text { appointment scheduling } \\
\text { activities at OS }\end{array}$ & $\begin{array}{l}\text { Independent variables: } \\
\text { indicators in priority activities } \\
\text { in the model by specialty } \\
\text { service in convergence or } \\
\text { interdependence with KPIs that } \\
\text { affect the dependent variables } \\
\text { as a whole or the results in } \\
\text { quality and patient safety in } \\
\text { HSH services and care }\end{array}$ & $\begin{array}{l}\text { Development of an } \\
\text { own measurement } \\
\text { framework for a } \\
\text { timely outpatient care } \\
\text { system and for health } \\
\text { preservation }^{3}\end{array}$ & $\begin{array}{l}\text { Level of } \\
\text { association or } \\
\text { correlation and } \\
\text { influence of } \\
\text { indicators on } \\
\text { the quality of } \\
\text { high specialty } \\
\text { services and } \\
\text { hospital care }\end{array}$ & $\begin{array}{l}\text { Architecture } \\
\text { analysis in } \\
\text { mappings, } \\
\text { with interviews } \\
\text { to stakeholder } \\
\text { and SIS } \\
\text { reports in } \\
\text { medical } \\
\text { specialty } \\
\text { services }\end{array}$ & $\begin{array}{l}\text { SIS/HIS to obtain lists } \\
\text { of appointments by } \\
\text { medical specialty; the } \\
\text { modules to request } \\
\text { appointments: } \\
\text { outpatient medical } \\
\text { specialty services in } \\
\text { the HSH }\end{array}$ \\
\hline
\end{tabular}

OS=outpatient services, $\mathrm{HSH}=$ high specialty hospital, $\mathrm{SIS}=$ services information system, HIS = hospital information system.

\section{Model of indicators in process architecture}

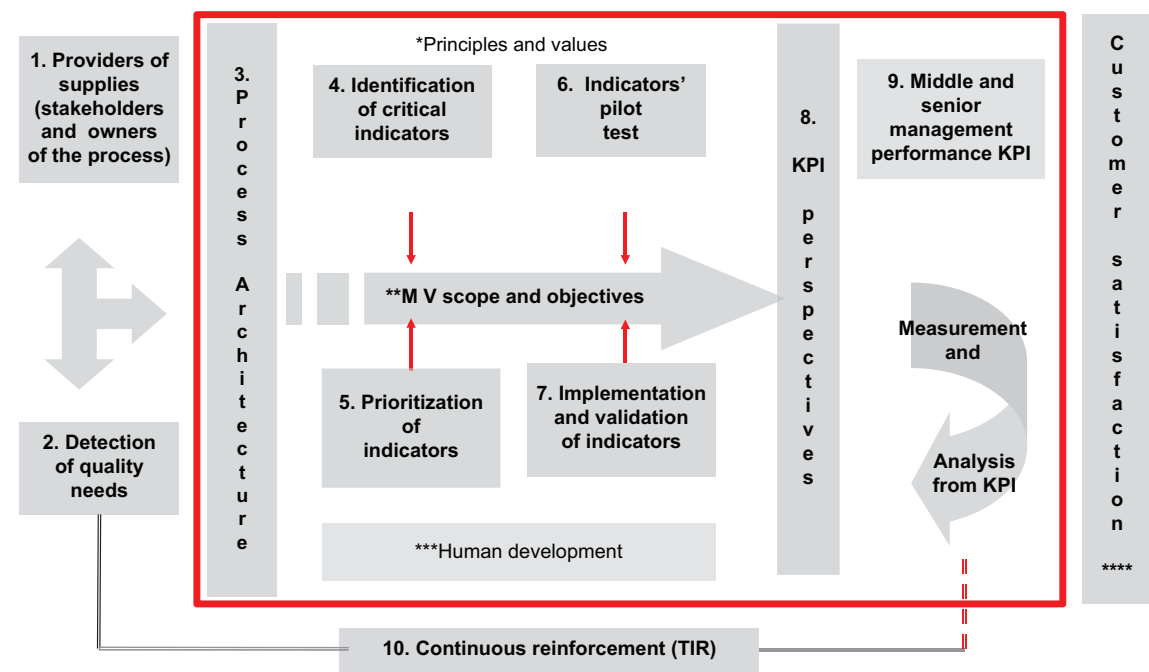

Figure 1. Model of indicators and process architecture in high specialty hospitals. TIR $=$ continuous reinforcement by levels, $K P I=k e y$ performance indicators. ${ }^{6}$

sector, with a structural ${ }^{8}$ and value chain analysis, ${ }^{9}$ which allows to analyze the stakeholders' effort to ensure medical care services, where public and private services and resources converge.

3. Process architecture. For PA, sub-processes and stages integration, processes are defined as sequences of logical, ordered stages that are repeatable and measurable, ${ }^{10}$ where two or more stakeholders participate for the production of a good or service. Strategy is the way defined, clear, measurable objectives, which are part of the mission and vision, are achieved; it constitutes the means and the actions through which the objectives will be achieved, with different activities to offer a good or service with a single value $^{11}$ to the customer, user and interested party; the generation of interdisciplinary and cross-sectional process maps was considered, based on interviews to the stakeholders about the process and activities they carry out.

3.1. Redesign of activities. It is achieved through the analysis of each activity, identifying those that are priorities, and categorization of the value to the customer and the organization. ${ }^{12}$

3.2.PA modeling. PA is the structural design, the structure of a model of processes that visualizes the configuration of a value chain that allows to closely link the break-up of sub-processes or stages of the operative process, which represents the standardization and integration level of the business processes. It 


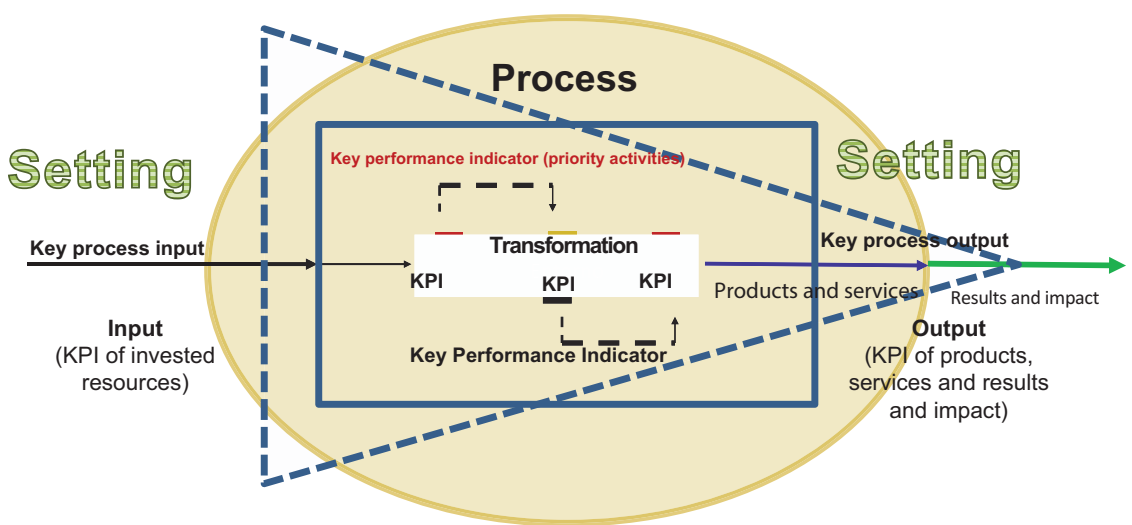

Figure 2. KPI for process priority activities and levels of strategic alignment. KPI = key performance indicators. Source: Own creation based on the black box, where the triangular dotted line corresponds to the strategic pyramid with hierarchical levels: operational, tactical and strategic.

can be considered as a detailed and general visualization of how an organization will allow and execute strategies. ${ }^{6}$

4. Identification of indicators or key performance indicators (KPIs). The construction of the KPI architecture in priority processes of critical activities is based on obtaining process maps with their sub-processes and stages.

4.1 Choice of priority activities. The activity with the highest importance is chosen within the process, not necessarily among the supplies or results of the process for priority activities, which guarantees the expected result of the good or service (Figure 2). ${ }^{6}$

4.2 Definition of KPIs. Identification of priority indicators and definition of KPIs that yield useful, accurate, correct and important measurements enables a good strategy and assertive and relevant decision-making. KPI offers a visualization of the behavior of activities to anticipate the results and make decisions at any functional area where the activity is located.

Figure 2 shows that priority activities are identified in the value chain as single and distinctive activities; in addition, an overlapping triangular dotted line represents the visualization and unfolding of the strategic pyramid that the $\mathrm{HSH}$ should implement at its operational, tactical and strategic levels..$^{13,14}$

5. Prioritization of indicators or KPIs. For indicator categorization to be carried out, the prioritization matrix is used. When variables are more than 15 , the method is as follows: ${ }^{15}$ a) Select a process to analyze its indicators. b) Make a list of indicators. c) Define what consists each one of. d) Localize the detected KPIs. e) Determine the priority level of a variable: 0 if influence is absent, 1 if influence is potential. $\mathrm{f}$ ) Make the addition by rows and columns. g) The mobility index is obtained with the score of the rows; the weight percentage is calculated taking the addition as $100 \%$. h) The score when the columns are added yields the dependence index. i) Make a mobility and dependence percentage chart to establish a division and delimit the priority zone (Figure 3).

6. Indicators or KPIs pilot test. The purpose of the indicator is to measure the influence of variables that affect the products or services and as a whole, and the results of the provided quality.

7. Implementation and validation of indicators. It allows standardizing the main elements that integrate the indicator. It involves the design of cards for each type of indicator, which enable monitoring by the person responsible for reporting the advances.

8. Indicators or KPIs perspectives. It refers to the categorization of each group of indicators to visualize the advancement of objectives:

- Profitability (productivity). ${ }^{16}$ It refers to the return of investment and to obtaining financial benefits. For hospitals, it refers to health care services' outcomes.

- Activities. ${ }^{16}$ Priority link within the value chain for the obtainment of a good or service.

- Patient safety. Classification used for indicators that monitor the use of good preventive practices for the reduction of failures that cause adverse events in the granting of patient care. $^{3}$

- Supply. It is the value proposals the HSH offers with regard to its products or services. ${ }^{16}$ 


\begin{tabular}{|c|c|c|c|c|}
\hline Prog. No. & Variables & Code & Mob \% (Y) & Dep \% (X) \\
\hline 1 & Total appointments & $1 \mathrm{CE}$ & 8.1081 & 2.7027 \\
\hline 2 & Outpatient appointments deferral by medical specialty & DCEEsp & 4.7297 & 4.7297 \\
\hline 3 & $\begin{array}{l}\text { Degree of adaptation of the outpatient appointment indication, as well as its } \\
\text { adaptation to the relevant specialties }\end{array}$ & PERT ESP & 2.7027 & 11.4865 \\
\hline 4 & Analysis of the delay and its causes, at first-time appointments in saturated schedules & ANA & 4.7297 & 2.0270 \\
\hline 5 & Degree of compliance with OS Registry (affiliation data, other administrative data) & INC REG & 1.3514 & 10.8108 \\
\hline 6 & Detection and evaluation of duplicate records & DUPLIC & 2.7027 & 10.8108 \\
\hline 7 & $\begin{array}{l}\text { Record level in successive appointments provided at the office in case there is no } \\
\text { system or connection }\end{array}$ & FCONEX & 3.3784 & 8.7838 \\
\hline 8 & Percentage of appointment errors & CITA ERR & 6.0811 & 0.6757 \\
\hline 9 & Discharges & Altas & 9.4595 & 2.0270 \\
\hline 10 & Subsequent appointments & Csubs & 10.1351 & 0.6757 \\
\hline 11 & First-time appointments & C1a & 10.1351 & 1.3514 \\
\hline 12 & Medical productivity at outpatient services by specialty & PCEsp & 8.1081 & 2.0270 \\
\hline 13 & Percentage of previous confirmations in appointment books & CONF & 2.0270 & 2.7027 \\
\hline 14 & $\begin{array}{l}\text { Percentage of openings in schedules in relation to total available openings in the } \\
\text { appointment book }\end{array}$ & HUECO & 0.6757 & 11.4865 \\
\hline 15 & Periods of appointment books saturation in days & BLOQ & 4.7297 & 8.1081 \\
\hline 16 & Complaints and claims at OS & QUE+R & 4.0541 & 8.1081 \\
\hline 17 & Attended referrals & REF ATEND & 7.4324 & 2.7027 \\
\hline 18 & Outpatient appointments deferral & DIF CE & 5.4054 & 0.6757 \\
\hline 19 & Customer satisfaction rating in outpatient services & 19 SATIS CE & 4.0541 & 8.1081 \\
\hline $100 / 19=5.2$ & Total & & 100.0000 & 100.0000 \\
\hline
\end{tabular}

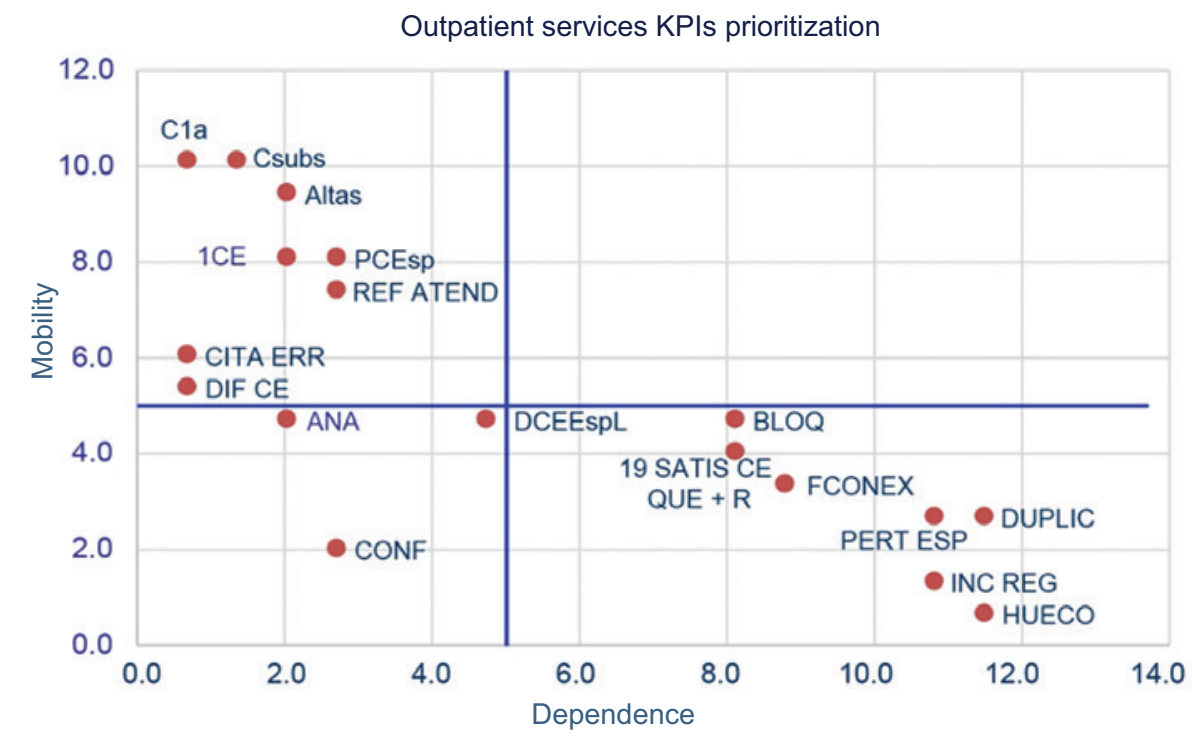

Figure 3. Outpatient service indicators prioritization. Source: own creation. 


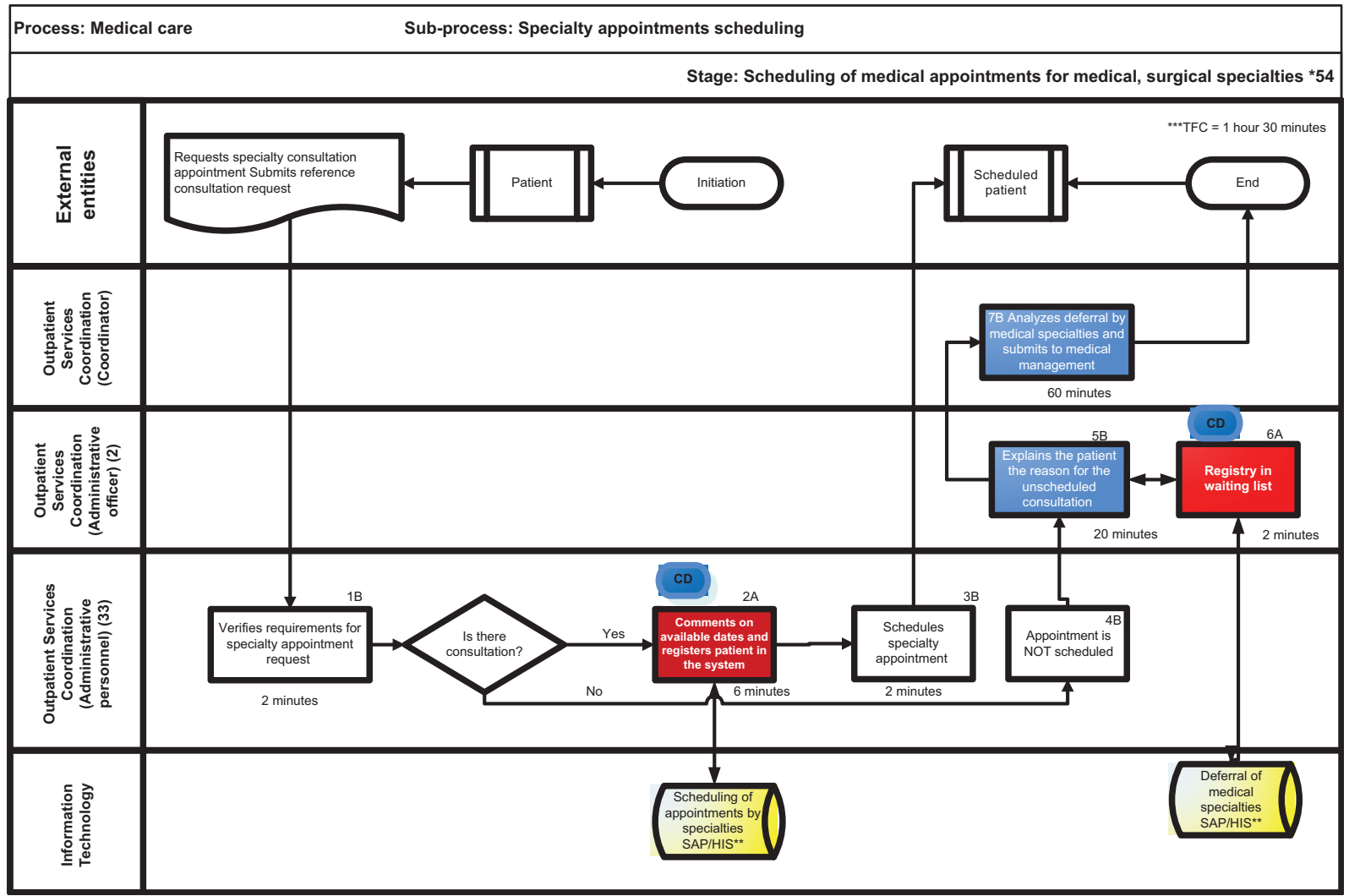

Figure 4. Architecture for the scheduling of medical appointments in outpatient services. Source: own creation.

- Quality. It comprises customer and affiliate satisfaction with the received goods or services.

- Health regulatory agencies. External public health entities designate monitoring and mandatory observance indicators. ${ }^{6}$

9. Performance KPIs at middle and high management levels. Strategic dashboards are a tool designed in a matrix-type structure. In the lateral part of the matrix, categorization classifications named Process perspectives are established. The description of their structural design is as follows: ${ }^{6}$

- Perspective. It allows indicators to be categorized in profitability (productivity), activities, patient safety, supply, quality and health regulatory agencies.

- Medical areas. It specifies the area of the organic structure the post belongs to.

- Objective. It identifies and qualitatively expresses the purposes towards which the resources, effort and activities of the organization should be directed to comply with the mission and vision.
- Strategy. It is the initiative that establishes how to achieve the objective and the goal that is sought in order to obtain the expected results.

- KPI indicator. It is the means, link or variable to measure values on a measurement scale, deriving from facts observed in the processes' priority activities.

- Indicator outcomes. They make sense in accordance with the established objectives (expected results) from which a series of activities are organized to achieve them. They include the following elements: a) Goal: quantitative element of the objective in time. b) Status: parameterization according to the advance of the results and that is assigned a green, red or yellow color depending on the highest or lowest permissible limit. It is plotted for visualization.

10. Continuous reinforcement by levels $(T I R) . .^{17}$ It is the good practices among the different participants and the active feedback that keeps the personnel motivated in order to generate a high level of commitment 


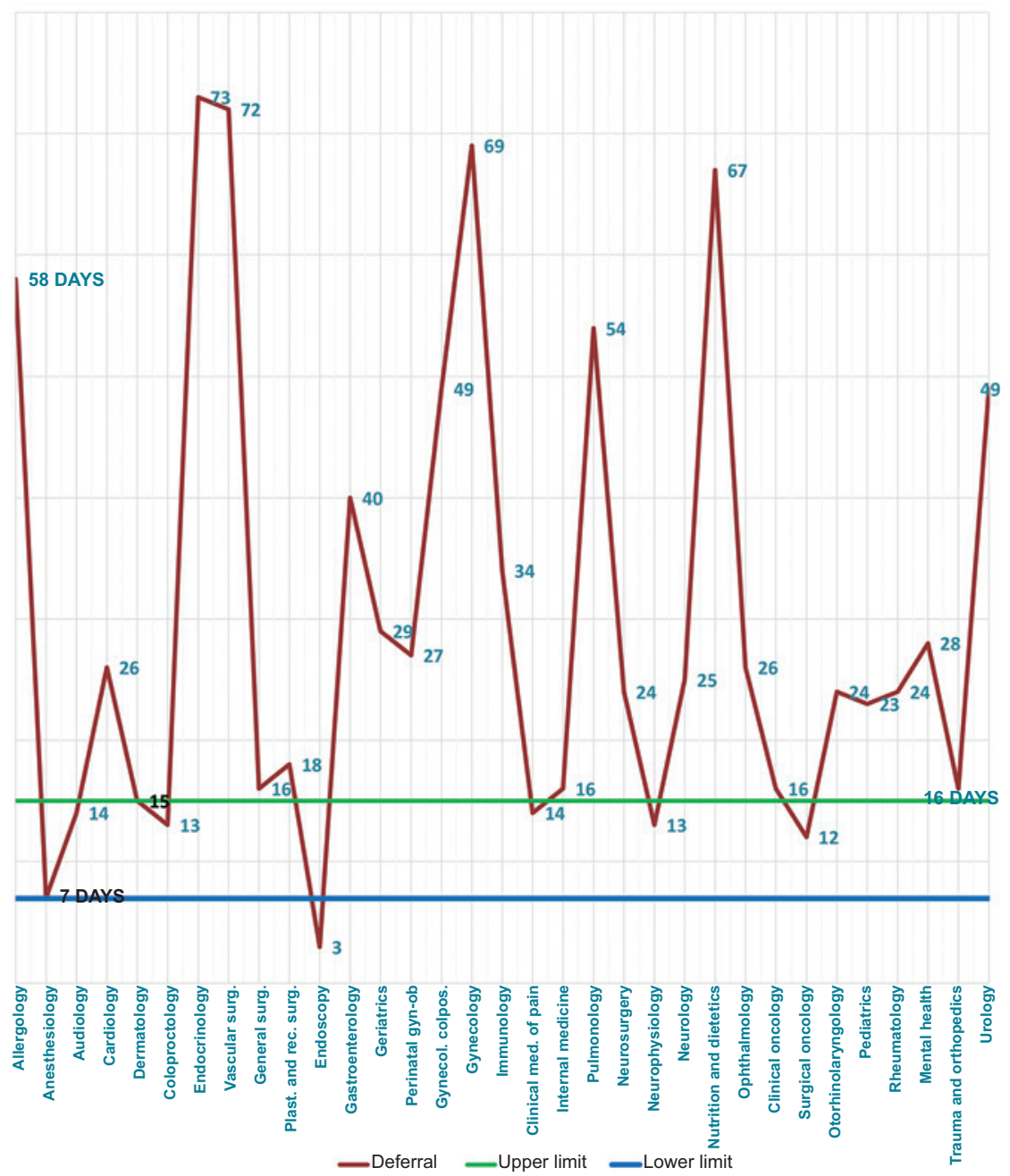

Figure 5. Specialty appointments' deferral longer than 15 and 20 days (upper limit). The green line corresponds to the higher limit of 15, and the blue line, to the lower limit of 7 days, with an average of 30 working days. Source: High-specialty public-private hospital within a 6-month period in 2017, with a survey of approximately 132,000 appointments.

\section{Results}

A diagram of patient care redesign in private-public hospitals (exclusive to a sector of government population) is presented in Figure 4.

$\mathrm{PA}$ is observed with cross-sectional and interdisciplinary mapping; stakeholders and owners of the process appear on the left side. It starts with a request at OS by clinical decision (referral). The $A$ activities in red are of priority value for the patient; $\mathrm{B}$ activities are of value, but only for the $\mathrm{HSH}$; the blue ones were added in the redesign in order to improve the OS process and to incorporate the consultation deferral (CD) and priority indicator. In yellow, the hospital or services information system. For follow-up in this pilot test with specialist physicians -students of the master's degree in Hospital
Administration of the National Autonomous University of Mexico-, the table in Figure 3 included the prioritization analysis of 19 OS indicators; those reported by the Ministry of Health are indicated in red, ${ }^{18}$ and those that are suggested appear in black. ${ }^{3}$

Figure 3 shows that CD appears in the priority quadrant, in addition to seven indicators of importance for which historical data were available. The CD KPI was validated, which is defined as the number of days the user is granted an appointment with, from the day he/ she requested it in the appointment book or as firsttime appointment. The algorithm is:

\section{Scheduled date-appointment date $=$ number of} deferral days by specialty

Having previously identified and analyzed the activity on the map of the process, allowed having 


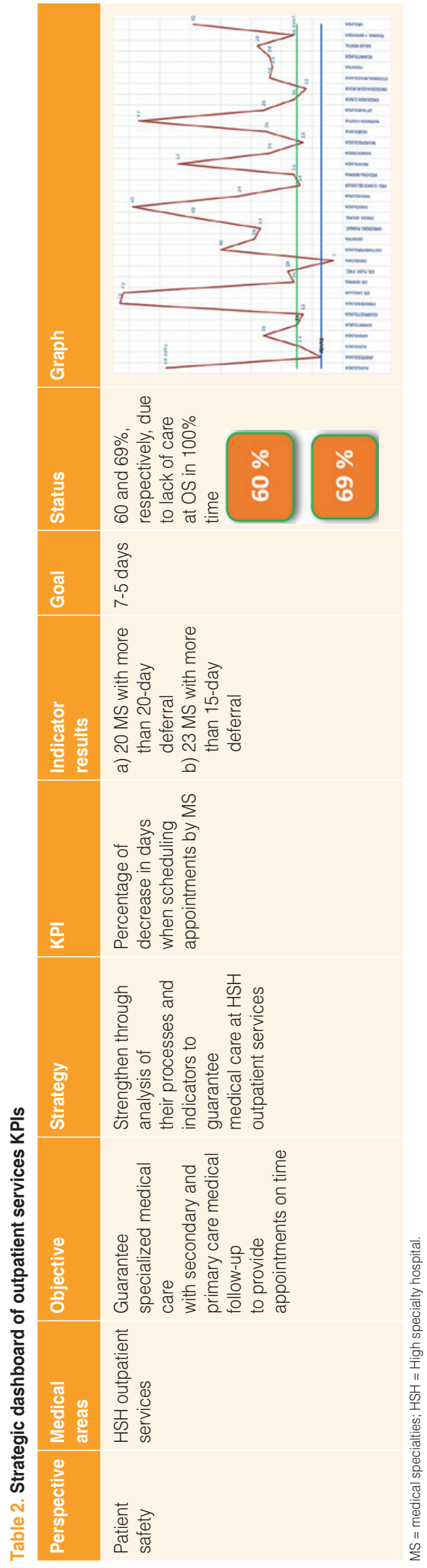

information to identify the cause for appointments with $\mathrm{CD}$ higher than 5 to 20 working days (limits vary according to the $\mathrm{HSH})^{18,19}$

Figure 5 shows the results of the pilot test in a public-private hospital with CD in 33 specialties in 2017; the dashboard construction as the final result is shown in Table 2.

\section{Discussion}

PA represents the level of activity integration and can be considered a detailed visualization on how the strategies are executed in an $\mathrm{HSH}$. The purpose of the $\mathrm{KPI}$ is not exclusively measuring the advances towards achieving expected results, but to make use of strategies that serve to decrease CD. In addition, it makes OS appointment scheduling cross-sectional mapping visible with the identification of KPIs, which allows measuring the results using indicators. Performing the calculation and analysis of $C D$ with the information system efficiency and its periodic report will allow resources to be requested by specialty. Scheduling online appointments and booking appointments on Saturdays with weekend shift medical staff is suggested to cover the demand.

\section{Conclusions}

This research presents the application of a case of success of the model of priority indicators of medical process architecture, which allowed to support and accept the hypothesis using a correlation analysis, which corresponded to 0.76 in the model implementation. The independent variables were adequately identified with indicators in priority activities of the process at OS according to the KPIs level of importance, to the benefit of medical care improvement

\section{Acknowledgements}

Thanks to the General Directorate of Academic Personnel Affairs, of the National Autonomous University of Mexico, for the support granted during the postdoctoral stay.

\section{References}

1. Subdirección General de Atención Especializada. Guía de gestión de consultas externas en atención especializada. España: Instituto Madrileño de la Salud; 2009.

2. Camino al Aseguramiento Universal en Salud (AUS). Resultados de la supervisión nacional a hospitales. Perú: Defensoría del Pueblo; 2013. 
3. Meena K, Thakkar J. Development of balanced scorecard for healthcare using interpretive structural modeling and analytic network process. J Adv Manag Res. 2014;11:232-256. DOI: 10.1108/JAMR-12-2012-005

4. La calidad de la atención a la salud en México. México: Biblioteca Mexicana del Conocimiento; 2016.

5. Girones-Muriel A, Matute E, González-Perrino C, Serradilla-Mateos L, Molinero T, Mariné M. Resultados globales en un hospital privado sobre su modelo de gestión quirúrgica. CMA. 2013;18:61-67.

6. Torres-Salgado MK, Vega-Lebrún CA. Arquitectura de indicadores estratégicos para elevar la calidad de los servicios médicos de los hospitales de alta especialidad. Investigación y Ciencia de la Universidad Autónoma de Aguascalientes. 2018:73:84-94.

7. Heredia-Álvaro JA. Sistema de indicadores para la mejora y el control integrado de la calidad de los procesos. España: Athenea; 2001.

8. Porter ME. Ser competitivo. España: Ediciones Deusto; 2012.

9. Porter ME. Ventaja competitiva, creación y sostenimiento de un desempeño superior. México: Pirámide; 2010.

10. Guía para la elaboración del Programa Institucional de Desarrollo Informático. México: Instituto Nacional de Estadística y Geografía; 2002.
11. Porter ME.¿Qué es la estrategia? Harvard Business Review. 2011: 100-117.

12. Hammer M, Champy J. Reingeniería. España: Grupo Editorial Norma; 2005.

13. Ludwig von-Bertalanffy K. Teoría general de los sistemas. México: Fondo de Cultura Económica; 2004.

14. David FR. Conceptos de administración estratégica. México: Pearson Educación; 2013.

15. Mojica-Sastore F. El método del análisis estructural: sus alcances y utilización. La perspectiva: técnicas para visualizar el futuro. Colombia: Legis Fondo Editorial; 1991.

16. Simon D, Fischbach K, Schroder D. Enterprise architecture management and its role. EE. UU.: Springer-Verlag Berlin Heidelberg; 2013.

17. Accenture BI. Human capital management mensurement break through on the horizont. EE. UU.: The Best-Run Businesses Run SAP; 2017.

18. Secretaría de Salud. Innovaciones en gestión hospitalaria en México. E caso de los hospitales regionales de alta especialidad. México: Secretaría de Salud; 2006.

19. Instituto Mexicano del Seguro Social. Manual metodológico de indicadores médicos 2019. México: Instituto Mexicano del Seguro Social; 2019. 